\title{
Improving Energy Efficiency with the Risk of Investment of Reference to Urban Development of Zielona Góra
}

\author{
Maria MRÓWCZYŃSKA, Andrzej ŁACZAK, Anna BAZAN-KRZYWOSZAŃSKA, Marta SKIBA
}

\begin{abstract}
The purpose of this article is a risk assessment of investments aimed at increasing the energy efficiency of urban development, in accordance with the terms agreed in the common EU policy, which would be cost-effective and optimal in technical, social and political terms. Factors affecting the change in the energy efficiency of selected buildings were determined by using multi-criteria comparative analysis. An attempt was made of economic justification of future energy-efficient building on the example of research carried out in the area of one of the quarters of Zielona Góra, taking into account a possibility of gaining funds from the European Union in a new 2014-2020 perspective. Investment activities were prioritized on the basis of the achieved synthetic indexes, hence giving the answer on priority in establishing activities in local politics.
\end{abstract}

Keywords: energy efficiency improvement; methods of multi-criteria analysis; risk of investment financing; urban policy

\section{INTRODUCTION}

EU climate and energy policy are inseparably linked, and achievement of objectives intended in the programme documents concerning energy efficiency supports the implementation of joint actions in this field. This is confirmed by the actions of the associated countries in 1995-2011, which led to a decline in energy intensity of the EU economy by $24 \%$, and $30 \%$ in the industrial sector. Furthermore, the share of energy from renewable sources in the total energy consumption, increased to $13 \%$ in 2012 and is expected to further increase this rate to $21 \%$ in 2020 and up to $24 \%$ in 2030 [1].

Reducing consumption of thermal, electrical and gas energy and an increase in the efficiency of devices in buildings is the main objective of the energy policy at regional, national and international levels today. This goal is also reflected in the local policy, setting out the scope for investments. The popularity of smart ways to design and construct more energy-efficient buildings, as well as increase their comfort has been growing in construction and architecture [2-5].

Meanwhile, the participation of cities in the global consumption of energy is constantly increasing and there is no indication that this trend will change. Increasing population, increasing demand for construction services and raising the level of comfort, with the increase in time spent in buildings, provides the upward trend in energy demand [6]. The global share of energy consumption by residential and commercial buildings has increased in recent years, reaching a level of between $20 \%$ and $40 \%$ in developed countries [7]. In the countries of Central and Eastern Europe particularly residential buildings and public buildings are characterized by high energy consumption [2].

For the EU's energy efficiency policies buildings are the key. More than $40 \%$ of final energy consumption takes place in homes, offices, shops and other facilities. On the other hand, the construction industry has the second largest, after the energy sector, unused and cost effective energy saving potential $[8,9]$.

EU directive on energy efficiency [10] imposes on Member States the obligation to ensure that, as from 1
January $2014,3 \%$ of the total floor area of heated and/or cooled buildings owned and occupied by its central government is renovated to meet at least the minimum energy performance requirements set for new buildings, in accordance with the assumption that the buildings of the public administration shall be models for others. At the same time, it requires the establishment of a system requiring energy efficiency, imposing on all energy distributors and/or retail energy sales companies the obligation to achieve the total savings target equal to $1.5 \%$ of the annual energy sales to final customers.

Among the methods that can be used as a tool to support decision making, dynamically developing methods of multi-criteria decision support are worth mentioning [11]. In the presented work, in order to assess the risk of investments aimed at improving the energy efficiency of the urban development, of many criteria possible to be used in the analysis, the ones that are most relevant to the decision maker and at the same time, discriminatory in nature were assumed. The analysis was based on four main groups of criteria: technical, economic, social and legal-political, for which parameter values were set, using information obtained from independent experts and that from existing documentation [12].

The energy efficiency of Polish cities is likely to remain at a low level. The reason for this are: an old average age of buildings, outdated energy grid and worn out, obsolete equipment (heat sources). A large part of the existing buildings in the Polish cities is energy-intensive, in a low standard. At the same time, the average size of dwelling, per person, constantly increases which forces the development of the construction industry and, at the same time, causes an increase in energy demand. According to GUS data over a period of ten years between 2001 and 2011, the average individual energy consumption has increased from 90 Mtoe to 102 Mtoe. The most energy is consumed by heating the rooms, cooking meals, and electrical equipment, including lighting [13].

The risk of financing investments can be a subject to mathematical analysis based on certain risk assessments that are created on the basis of independent expert advice 
and the data contained in the available documentation. Risk is often divided to: very high, high, medium and low, taking into account the probability of occurrence and the financial, and organizational consequences and implications for health and safety, if such a risk occurred [14].

Scientific literature indicates the relationship between investment and technology. Regardless of this, uncertainty of the legal framework significantly changes the investment patterns. A study, conducted by Sisodia with a team focuses on modelling activities using renewable energy sources with the assessment of business risk in Iberia and is associated with the current changes in energy regulation in Spain [15]. Request for further research should be to take into account the impact of additional factors, such as the cost of building materials, the price of land fluctuations, project management, construction failures, strikes, natural disasters, changes in labour markets, etc. Other variables that can be crucial for future research are the impact of the competitiveness of the local markets and the determination of the financial support for RES [15-17].

Any mathematical model is dependent on the uncertainty associated with both the choice of parameters and the structure of the model. Chalabi with the team presented a standard method of quantitative determination of uncertainty in risk models series, where the output of one and the entrance to another model is made with the use of a probabilistic simulation, which is algebraically, using integral transforms [18]. When assessing the risk of increasing the energy efficiency of buildings associated with the policy and intervention, it is important to take uncertainty and variability into account in created models. The inclusion of these two questions can help making the right decisions based on the possessed data [18]. Multicriteria analysis can be used as a method of assessment of risk of planned investments and can be complementary to other analyses, especially: economic, costs and benefits analyses. In order to obtain reliable results, all the factors that have influence on taking a final decision on the planned investments need to be concerned in the analysis For all identified in the decision-making criteria measures need to be specified, encoding must be made and a synthetic price classifying different categories depending on the risk of buildings planned investments must be finally calculated. In the presented study, a single-family residential development had the lowest risk of investment and industrial buildings had the biggest.

Risk analysis is a systematic approach, taking into account, as much as possible, a complete evaluation of the risk factors, used transparently and comprehensively and considering existing uncertainty or lack of knowledge [19, 20].

Technical risk has been multi-criteria identified in the study. First, as the age of an object, it is associated with a durability of the structure and its individual elements. Construction time affects the investment risk. The older the building the greater the risk that the cost of carrying out the potential renovation for the surveyed buildings in order to receive full technical and functional performance, will increase. Secondly, the buildings are classified by dividing them to those made in traditional and industrialized technology or partly-industrialized. The industrialized technology allows reducing the investment risk through activities standardized in the region and the country. Buildings made in traditional technology are characterized by individual form, which increases the risk of optimal selection of activities that increase energy efficiency. Energy price largely depends on the source used to obtain thermal energy for heating the building and preparing hot water. In the zone no 40 in Zielona Góra, most of multi-family and commercial buildings are powered by a combined heat and power plant, which produces combined heat characterized by a low market price. For single-family buildings gas is the dominant source of heat. Technical requirements to comply with the requirements of the $\mathrm{EU}$ in energy efficiency were concerned as a technical risk. There is a slight possibility for all new investments, that not all national and EU regulations will be considered in progress. The implementation of public investment carries a slight risk of non-compliance with the applicable regulations. On the contrary, in case of single-family buildings, the risk of non-compliance with the rules is relatively large. Currently there are few effective methods of an individual investment control.

\section{CHARACTERISTICS OF ZIELONAGÓRA DEVELOPMENT}

In ZielonaGóra, as in most Polish cities, the structure of the buildings is varied. Dense frontage development, made in traditional technology occurs in the old town, where carbon heating equipment is still in use. These are often residential and commercial-residential buildings. Due to the technology implemented and the quality of the materials used, they are very energy-intensive buildings, often not thermally insulated. The old town and the city centre are surrounded by a ring of housing estates with residential multi-family buildings constructed at various periods from the 1950 s to the present. The estates are characterized by traditional or industrialized technology of the development implementation. Detached houses, semi-detached and terraced ones built in traditional technology, are located mainly in the suburbs [12]. For the Energy Audit of Zielona Góra carried out in 2011, the city was divided into urban construction zones. In the presented work, a research based on the selection of data for the reference buildings was used. A reference building shall be understood as the same as for shape, structure, function and usage, as an assessed building. Reference buildings are characterized by the location in a development zone no 40, selected for analysis for the purposes of this article (fig. 1). The analysed zone no 40, is one of 50 zones, highlighted in the Energy Audit for Zielona Góra [12]. The area is dominated by singlefamily buildings, made in traditional technology and multi-family buildings, 4 and 11 storeys, built mostly in the 1970s, precast technology. They are complimented by commercial two storey buildings including: a primary school, social care home, shopping centre and individual industrial buildings. Buildings in the zone no 40 are mostly heated by the municipal CHP. In case of upbringing buildings to $75 \mathrm{kWh} / \mathrm{m}^{2} /$ year standard, the estimated amount of saved energy total may reach 
$19721.08 \mathrm{MWh} /$ year that is 4024.71 [toe], which is 19.7 GWh (Tab. 1).

On the basis of the analysis of thermal upgrading renovation cost estimates and energy audits of the reference buildings, it is assumed that improving energy efficiency will occur as a result of:

- thermal upgrade of old residential buildings and public buildings,
- development of smart grid and smart metering,

- $\quad$ the use of modern technology to power management, for example stairway lighting, monitoring energy use in buildings, etc.,

- cooperation with the inhabitants of the houses and buildings zones covered by the plan to raise energy efficiency.

Table 1 The total usable space in the zone no 40 in Zielona Góra, and the average cost of the investments (PLN/m²) assumed on the basis of calculations carried out for reference buildings [12

\begin{tabular}{|c|c|c|c|c|c|}
\hline No & Type of development & $\begin{array}{l}\text { Usable area (gross) } \\
\qquad\left(\mathrm{m}^{2}\right)\end{array}$ & $\begin{array}{c}\text { The average energy } \\
\text { savings as a result of } \\
\text { the thermal upgrading } \\
\left(\mathrm{kWh} / \mathrm{m}^{2} / \text { year }\right)\end{array}$ & $\begin{array}{c}\text { The average } \\
\text { investments cost } \\
\left(\mathrm{PLN} / \mathrm{m}^{2}\right)\end{array}$ & $\begin{array}{l}\text { The total saved energy } \\
\text { in MWh/year (toe) }\end{array}$ \\
\hline 1. & Services & 33354 & 68 & 258.2 & $2268.07(230)$ \\
\hline 2. & Production & 3531 & 199 & 122.4 & $702.67(234.7)$ \\
\hline 3. & Single-family residential & 56566 & 105 & 162.6 & $5939.43(23.5)$ \\
\hline 4. & Multi-family residential & 102961 & 105 & 269.8 & $10810.91(284.3)$ \\
\hline \multicolumn{2}{|r|}{ TOTAL } & 196412 & & & 19721.08 \\
\hline
\end{tabular}

\section{SOURCES OF FINANCING ENERGY EFFICIENCY AND RENEWABLE ENERGY SOURCES}

There are many sources of funding for actions aimed at improving energy efficiency of buildings and using RES. In 2007-2013 the most funds for this purpose were provided under the cohesion policy of the EU, including the funds dedicated to projects related to direct investment. The other, much lower funds and to a lesser extent, are provided on direct support for investments for low and zero energy demand.

Each EU Member State has benefited from these measures in different heights and allocated them on the achievement of the objectives arising from its specifics [21]. In 2007-2013, a total of 10 projects were completed in the field of energy efficiency and cogeneration on the territory of Zielona Góra. The projects were implemented within the two programs - Infrastructure and Environment Operational Programme, and Lubuskie Regional Operational Programme. The total value of the projects amounted to 81550787.78 PLN, including the subsidy from EU funds - 54444964.36 PLN. In the field of renewable energy only one project was completed valued at 606 543.96. It obtained a grant in the amount of 496 481.85 PLN [22].

Table 2 Funding for energy efficiency under the current Multiannual Financial Framework (2007-2013) [8]

\begin{tabular}{|c|c|c|c|}
\hline Source of funding & Instruments/mechanisms & $\begin{array}{l}\text { The total financial resources } \\
\text { available }\end{array}$ & $\begin{array}{c}\text { Funding for energy efficiency } \\
\text { (EE) }\end{array}$ \\
\hline Cohesion policy funding & $\begin{array}{l}\text { Operational programmes, } \\
\text { including financial instruments } \\
\text { (e.g. JESSICA) }\end{array}$ & $\begin{array}{c}10.1 \text { billion EUR } \\
\text { planned on sustainable energy } \\
\text { (RES \& EE) }\end{array}$ & $\begin{array}{c}5.5 \text { billion EUR planned for EE, } \\
\text { cogeneration and energy } \\
\text { management }\end{array}$ \\
\hline Research funding & $\begin{array}{c}7 \text { PR } \\
\text { (e.g. Concerto, E2B PPP, smart } \\
\text { cities) }\end{array}$ & $\begin{array}{c}2.35 \text { billion EUR } \\
\text { for research in the field of } \\
\text { energy }\end{array}$ & $\begin{array}{l}290 \text { million EUR } \\
\text { for energy efficiency }\end{array}$ \\
\hline $\begin{array}{l}\text { The financing of the } \\
\text { enlargement policy }\end{array}$ & $\begin{array}{l}\text { Financial facilities of } \\
\text { international institutions } \\
(\mathrm{SMEFF}, \mathrm{WRF}, \mathrm{EEFF})\end{array}$ & $\begin{array}{l}552.3 \text { million EUR } \\
\text { (that is } 381.5+117.8+53 \text { ) }\end{array}$ & $\begin{array}{l}\text { About one-third of the total } \\
\text { project financing for industry } \\
\text { and buildings }\end{array}$ \\
\hline $\begin{array}{c}\text { The European Energy } \\
\text { Programme For Recovery } \\
\text { (EEPR) }\end{array}$ & $\begin{array}{c}\text { The European Fund For Energy } \\
\text { Efficiency (EFEE) }\end{array}$ & 265 million EUR & $\begin{array}{l}70 \% \text { of the appropriations to be } \\
\text { allocated to energy efficiency }\end{array}$ \\
\hline $\begin{array}{l}\text { Competitiveness And } \\
\text { Innovation Programme (CIP) }\end{array}$ & $\begin{array}{c}\text { The Intelligent Energy-Europe } \\
\text { Programme } \\
\text { (including ELENA) } \\
\text { The Information } \\
\text { Communication Technologies } \\
\text { Policy Support Programme } \\
\text { (ICT-PSP) }\end{array}$ & $\begin{array}{c}\text { About } 730 \text { million EUR for each } \\
\text { programme }\end{array}$ & $\begin{array}{c}\text { About } 50 \% \text { of the funds } \\
\text { allocated to energy efficiency in } \\
\text { all sectors }\end{array}$ \\
\hline
\end{tabular}

Significant funds on energy efficiency and RES were included in the European Structural and Investment Funds for the period 2014-2020. Under the Regional Operational Programme-Lubuskie 2020 more than 450 million has been allocated for all activities associated with the lowcarbon economy, which also include energy efficiency and investment in RES. It is difficult today to determine what amount will go to Zielona Góra probably, it will be about $10-15 \%$. Beneficiaries may also apply for support from the Infrastructure and Environment Operational Programme. Investments to raise energy efficiency and RES can be supported within the priority axis 1 Decarbonization of the economy. For this purpose a total of 7.86 billion is provided. The experience of the past years shows that a small part of this amount will go to Zielona Góra. 


\section{THE RESEARCH AND THE CONCLUSIONS}

Identified economic risk is primarily linked to the price of energy. Energy prices are relatively stable. Analysts do not predict an increase in prices. Diversification of supply and sources can give hope to reduce or at least stability of prices. Also the possibility of the use of EU funds affects the local policy. Improving energy efficiency of multi-family buildings is a priority for the EU. This is reflected in the support of such investments from EU funds. The problem, however, is that compared to needs the funds are far too small. Therefore, the risk of not receiving funds is quite large. EU policy basically provides no support for single-family buildings in energy efficiency. Therefore, the risk of not getting the support is very large. Improving energy efficiency in public buildings is still supported within the EU policy. However, more emphasis is put on multifamily buildings. The risk of not receiving funds should be estimated as medium. Next, support for energy efficiency businesses is one of the most important priorities of the EU. Entrepreneurs have many opportunities of obtaining EU support. Therefore, the risk of not receiving funds is low.

Political and legal risk is associated with the State policies in terms of energy efficiency investments. It is dependent on making plans and programmes which support improving the efficiency of buildings and on sustainable actions. Frequent political changes mean that there is a very high risk of destabilizing activities in the field of directions of support and promotion. The least susceptible to political changes are activities related to single-family buildings and production buildings, where investors seeking to reduce operating costs are determined and take actions to improve energy efficiency on the basis of the economic conditions, regardless of the State and local authorities policy. This is different in case of energy efficiency investments in public buildings. Co-financing of this kind of buildings is dependent on the policy, and the frequent political changes mean that there is a high risk.

One of the methods that might be used to support the decision-making process with the minimization of risk is a multi-criteria comparative analysis method, which allows choosing the most favourable option of investment solutions. For the risk evaluation the multi-criteria analysis was applied in the study to assist the decisionmaking process in case of multiple criteria, and its main goal is to achieve one result on the basis of the possessed information [23, 24]. In this method, a model is not formed in details, therefore it takes discrete values, a set of possible decisions is limited and countable. It is worth noting that the investment risk assessment criteria should be representative for the project concerned, sufficiently detailed and should be referred to the relationship between the criteria chosen for the analysis. In order to determine the risk of investments to improve the energy efficiency of urban development mathematical methods were used, which are a group of algorithms included in the methods of the multi-criteria comparative analysis. Mathematical methods are methods that are based on clear and known formulas and they are among the most used methods to support decision making. In the process of multi-criteria analysis both measurable and immeasurable features, being a subject to the process of quantification (ultimately are numeric values) can be used. In mathematical methods, an important element is the encoding of the measures adopted for the analysis, in order to replace a nominal value of a partial measure with a pure (numeric) value from a specified range [25]. Coding defines an algorithm of mathematical method, the following can be distinguished: standardization, normalization, Neumann-Morgenstern or Pattern method. In the study, encoding the criteria was carried out by standardization according to the following formulas:

When the criterion is the activator:

$z_{i j}=\frac{x_{i j}-\bar{x}_{j}}{s_{j}}$.

When the criterion is the inhibitor:

$z_{i j}=\frac{x_{i j}-\bar{x}_{j}}{s_{j} \quad}=(-1) \frac{x_{i j}-\bar{x}_{j}}{s_{j}}$,

where: $x_{i j}$ - original measure of $i^{\text {th }}$ variant according to the $j^{\text {th }}$ criterion, $z_{i j}$ - coded measure variant, $x_{j}$ - average of measures of analysed variants according to $j^{\text {th }}$ criterion, $s_{j}$ standard deviation. Standardized criteria values are summarized in Tab. 1. In the next step, the investment risk assessment was made by calculating the synthetic index (Tab. 1), using the formula:

$J_{i}=\sum_{j=1}^{m} z_{i j}$

The risk can be defined as existence of uncertainty of appearing adverse events. Thermal upgrading are relatively low-risk investments. The thermal upgrading always leads to significant savings in energy consumption. With really constant, possible to estimate costs associated with energy consumption, the cost and investment risk can be easily estimated. The investment risk in terms of energy efficiency of buildings is presented in Tab. 3, where four groups are shown: technical, economic, social and legal factors influencing the investment risk improving energy efficiency of buildings in the zone no 40 in Zielona Góra. Buildings corresponding to the four groups of reference buildings for which the research on final energy consumption on the basis of actual costs was presented in details, have been identified in this area [12]. Division of building zones is as follows:

Group 1 - dominating development with co-operative and communal buildings, low-standard multi-family buildings, constructed in 1971-1980 in industrial technology, heated with combined heat from municipal CHP plant;

Group 2 - development dominated by single-family, detached, freehold buildings, constructed in 1960-1980 by traditional technology, where gas is the source of energy needed for heating and warming water; 
Group 3 - development dominated by public buildings like school and social care home, built in the years 1971-1980, powered by combined heat, owned by the municipality of Zielona Góra;

Group 4 - mainly industrial development, buildings constructed in the 1960s-1980s, owned privately and municipally, in partly-industrialized technology, powered by gas.

Table 3 Factors affecting the risk of investment to improve energy efficiency in certain groups of buildings located in the zone no 40

\begin{tabular}{|c|c|c|c|c|c|c|}
\hline \multicolumn{3}{|c|}{$\begin{array}{c}\text { The selected factors of investment risk } \\
\text { assessment }\end{array}$} & \multirow{2}{*}{$\begin{array}{l}\frac{0}{00} \\
\frac{00}{\exists} \\
\frac{2}{0} \\
+ \\
+\end{array}$} & \multirow[t]{2}{*}{ 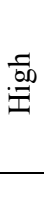 } & \multirow[t]{2}{*}{ 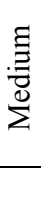 } & \multirow[t]{2}{*}{$\stackrel{3}{3}$} \\
\hline \multirow{16}{*}{ 导 } & \multirow{4}{*}{$\begin{array}{c}\text { Construction time } \\
(1960-1980,1971-1980)\end{array}$} & 1 & & & & \\
\hline & & 2 & & + & & \\
\hline & & 3 & & + & & \\
\hline & & 4 & & & + & \\
\hline & \multirow{4}{*}{$\begin{array}{l}\text { Technology } \\
\text { (traditional, precast, partially- } \\
\text { precast) }\end{array}$} & 1 & + & & & \\
\hline & & 2 & & + & & \\
\hline & & 3 & & & & + \\
\hline & & 4 & & & + & \\
\hline & \multirow{4}{*}{$\begin{array}{l}\text { The heat source } \\
\text { (cogeneration, gas) }\end{array}$} & 1 & + & & & \\
\hline & & 2 & + & & & \\
\hline & & 3 & & + & & \\
\hline & & 4 & & + & & \\
\hline & \multirow{4}{*}{$\begin{array}{l}\text { Technical requirements to } \\
\text { comply with the requirements of } \\
\text { the EU in energy efficiency }\end{array}$} & 1 & + & & & \\
\hline & & 2 & & + & & \\
\hline & & 3 & + & & & \\
\hline & & 4 & & & & + \\
\hline \multirow{8}{*}{ 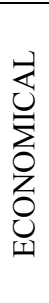 } & \multirow{4}{*}{ The increase in energy prices } & 1 & & & + & \\
\hline & & 2 & & + & & \\
\hline & & 3 & & & + & \\
\hline & & 4 & & & + & \\
\hline & \multirow{4}{*}{$\begin{array}{l}\text { The possibility of the use of EU } \\
\text { funds }\end{array}$} & 1 & & + & & \\
\hline & & 2 & & & + & \\
\hline & & 3 & & + & & \\
\hline & & 4 & + & & & \\
\hline \multirow{8}{*}{$\underset{\mho}{\circlearrowright}$} & \multirow{4}{*}{$\begin{array}{c}\text { Object functions } \\
\text { (multi-family housing, single- } \\
\text { family housing, commercial, } \\
\text { industries) }\end{array}$} & 1 & + & & & \\
\hline & & 2 & + & & & \\
\hline & & 3 & & & + & \\
\hline & & 4 & & & + & \\
\hline & \multirow{4}{*}{$\begin{array}{c}\text { Ownership } \\
\text { (private, cooperative, communal) }\end{array}$} & 1 & & & + & \\
\hline & & 2 & + & & & \\
\hline & & 3 & & & + & \\
\hline & & 4 & & + & & \\
\hline \multirow{4}{*}{ 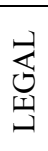 } & \multirow{4}{*}{$\begin{array}{c}\text { Records of the planning } \\
\text { documents and covered by a } \\
\text { programme for increase in energy } \\
\text { efficiency }\end{array}$} & 1 & & & & + \\
\hline & & 2 & + & & & \\
\hline & & 3 & & & + & \\
\hline & & 4 & & + & & \\
\hline
\end{tabular}

Presented research aimed at assessing the risk of achieving the goal, which is to improve the energy efficiency of the urban development on the example of Zielona Góra. Studies were carried out in the following stages:

- $\quad$ an indication of the reference buildings,

- defining energy efficiency improvement measures, to be applied in relation to the reference buildings,

- analysis of activities reducing the final energy demand, based on the thermal upgrading cost estimates and energy audits of reference buildings,
- $\quad$ estimating the cost of increased energy efficiency, 1 $\mathrm{kWh} / \mathrm{m}^{2} /$ year, in relation to the buildings in the zone no 40 ,

- defining a set of criteria (technical, economic, social and legal), affecting the risk of investments to improve energy efficiency,

- $\quad$ assessing risk with a use of the multi-criteria analysis method.

The criteria that were taken into account have been rated in terms of possible risk, separately for each of the four groups of buildings located in the zone no 40 . On the basis of the opinion of independent experts and available documentation the following risk was assessed:

- $\quad$ very high - very high probability of investment risk and its severe effects,

- high - high probability of investment risk and its severe effects,

- medium - low probability of investment risk and its effects less severe,

- $\quad$ low - means acceptable investment risk.

In order to apply mathematical methods, for the purposes of this work, risk assessment in the linguistic form (very high, high, medium and low), was replaced by numeric values, determining the probability of the risk and its possible effects. Then the criteria coding was made according to patterns (1) and (2), and eventually a synthetic assessment of individual solutions was made according to (3)

The assumptions allowed to assess investment risks depending on the analysed factors for particular groups of buildings located in this zone. The best solution, concerning actions taken to improve energy efficiency (the smallest investment risk) applies to a category of buildings where the value of the synthetic assessment is the biggest, the greatest risk applies to the category of buildings where the value of the synthetic assessment is the smallest (a choice of this type of investment is the least beneficial taking into account the analysed criteria). As seen in the data contained in table 4, the most beneficial option, with the lowest risk investment, designed to increase energy efficiency, is an improvement of efficiency of buildings defined in category 2 (singlefamily), while the greatest risk occurs for category 4 buildings (industrial buildings).

Point risk assessment enables organizing the risk types according to their weighting or criteria. On that basis a hierarchy of actions taken in order to reduce the investment risk can be made. There are following ways to respond to the risk: acceptance of risk (monitoring), minimizing the risk (necessary preventive action focused first on the consequences of the high level, or the likelihood of carrying out a risk), avoiding risk, transfer or risk diversification (eliminating at the source or reducing) [20].

Analysis of the factors and criteria is favourable to proper decision-making and the implementation of measures to achieve low (acceptable) level of the investment risk. The risk determines ability to success but also failure or loss.

Risk monitoring includes:

- review, to determine whether the risk has changed, 
- checking if point risk analysis is still relevant,

- ensuring the effectiveness of existing control mechanisms,

- monitoring the development of appointed actions in terms of risk management.

City policy should support changes to increase the energy efficiency of buildings and investments in RES. Energy policy should be more diversified and based on legal basis, giving a wider field of action of local governments in terms of specifying responsibility for individual country objectives, to which Poland was obtained at the level of the EU directives. According to analysis of the legislation currently in force in Poland, the legislature did not specify the tasks facing the local governments in terms of energy policy, in accordance with clearly defined country objective. It would be advisable to run programs to promote energy-efficient construction, so as to recommend potential investors beneficial solutions along with a possibility of financial support.

Table 4 Standardized criteria values

\begin{tabular}{|c|c|c|c|c|}
\hline \multirow[b]{2}{*}{ The criterion } & \multicolumn{4}{|c|}{ An indication of the reference buildings } \\
\hline & $\begin{array}{c}\text { Multi-family } \\
\text { buildings - } \\
\text { precast } \\
\text { technology }\end{array}$ & $\begin{array}{c}\text { Single-family } \\
\text { buildings - } \\
\text { traditional } \\
\text { technology }\end{array}$ & $\begin{array}{l}\text { Commercial } \\
\text { buildings - } \\
\text { traditional } \\
\text { technology }\end{array}$ & $\begin{array}{l}\text { Industrial } \\
\text { buildings - } \\
\text { precast } \\
\text { technology }\end{array}$ \\
\hline Construction time & 1.22 & 0.00 & 0.00 & -1.22 \\
\hline Implementation technology & 1.20 & 0.24 & -0.24 & -1.20 \\
\hline The dominant heat source (utilities) & 0.87 & 0.87 & -0.87 & -0.87 \\
\hline $\begin{array}{l}\text { Technical requirements to comply with the requirements } \\
\text { of the EU in energy efficiency }\end{array}$ & 0.71 & 0.00 & 0.71 & -1.41 \\
\hline $\begin{array}{l}\text { The cost of increase in economic efficiency of } 1 \\
\mathrm{kWh} / \mathrm{m}^{2} / \text { year }\end{array}$ & -0.50 & 1.50 & -0.50 & -0.50 \\
\hline The possibility of the use of EU funds & 0.35 & -1.47 & 0.36 & 0.76 \\
\hline Building's function & 0.87 & 0.87 & -0.87 & -0.87 \\
\hline Ownership & -0.85 & 1.04 & -0.86 & 0.66 \\
\hline Records of the planning documents & -0.39 & 1.51 & -1.16 & 0.39 \\
\hline Synthetic evaluation index & 3.48 & 4.21 & -3.43 & -4.26 \\
\hline
\end{tabular}

Municipalities and cities do not lead energy supervision. Due to a lack of examples, experience and detailed regulations, the methods and scope of activities and priorities must be created from the very beginning. Lack of knowledge, skills, and data in the municipalities generate high costs of making plans by outsource companies. The reason for the current state is the lack of a formal instrument of a city energy policy. To improve the energy efficiency of the municipalities, patterns and guidelines for shaping and monitoring of energy consumption must be introduced.

However, it seems that a necessary condition for the implementation of the energy-efficient renovations of city buildings is the development of complex programmes, especially for inner-city zones, covered in most cases with programmes to protect buildings or areas that will contribute to energy savings. Programs considering the comprehensive development and planned activities, including obtaining energy from RES, can be an opportunity for local governments. The regulations in these terms should be more radical, promoting green technologies.

Municipalities should identify clear objectives and regularly prepare reports on progress in increasing energy efficiency indicators in their areas and, according to their legal limits, support bottom-up initiatives aimed at engaging inhabitants to act out e.g. in terms of policies aimed at energy production from renewable sources, support of creative industry and knowledge-based business e.g. within the participatory budgets, as the most popular form of direct cooperation between the local government and inhabitants.

\section{Abbreviations}

EU - European Union

CHP - Combined Heat and Power

RES - Renewable Energy Source

EUR - Euro

EE - Energy Efficiency

EEPR - The European Energy Programme For Recovery

JESSICA - Joint European Support for Sustainable Investment in City Areas

E2B -Education to Business

PPP - Purchasing Power Parity

EFEE - The European Fund For Energy Efficiency

WRF - Weather Research and Forecasting

ELENA - European Local Energy Assistance

CIP - Competitiveness and Innovation Programme

ICT-PSP - The Information Communication Technologies

Policy Support Programme

GUS - Central Statistical Office

\section{Indices}

$i-$ variant according

$j-$ criterion

$m$ - criterion number

\section{Variables}

$x_{i j}$ - original measure

$z_{i j}$ - coded measure variant

$x_{j}$ - average of measures of analysed variants according to $s_{j}-$

standard deviation

\section{REFERENCES}

[1] Communication From The Commission To The European Parliament, The Council, The European Economic And 
Social Committee And The Committee Of The Regions COM (2014) 15, Brussels 22.01.2015.

[2] Balaras, C., Droutsa, K., Dascalaki, E., \& Kontoyiannidis, S. (2005). Heating energy consumption and resulting environmental impact of European apartment buildings. Energy and Buildings, 37, 429-442. https://doi.org/10.1016/j.enbuild.2004.08.003

[3] Fabbri, K., Zuppiroli, M., \& Ambrogio, K. (2012). Heritage buildings and energy performance: Mapping with GIS tools. Energy and Buildings, 48, 137-145. https://doi.org/10.1016/j.enbuild.2012.01.018

[4] Sabonnadière, J-C. \& Quenard, D. (2009). Low Emission Power Generation Technologies and Energy Management.

[5] Kazak, J., van Hoof, J., \& Szewranski, S. (2017). Challenges in the wind turbines location process in Central Europe - The use of spatial decision support systems. Renewable and Sustainable Energy Reviews, 76, 425-433. https://doi.org/10.1016/j.rser.2017.03.039

[6] Raatikainen, M., Skön, J-P., Leiviskä, K., \& Kolehmainen, M. (2016). Intelligent analysis of energy consumption in school buildings. Applied Energy, 165, 416-429. https://doi.org/10.1016/j.apenergy.2015.12.072

[7] Harris, N. (2010). Discretion and expediency in the enforcement of planning controls. The Town Planning Review, 81(6), 675-700. https://doi.org/10.3828/tpr.2010.26

[8] Report From The Commission To The European Parliament And The Council Financial support for energy efficiency in buildings $\operatorname{COM}(2013) 225$ of 18.04.2013.

[9] Alsabry, A. (2016). Possibilities of decreasing energy consumption through thermal upgrading in selected buildings in Poland case study: The town of Zielona Góra. Energy and Buildings, 130, 811-820. https://doi.org/10.1016/j.enbuild.2016.09.004

[10] Directive of The European Parliament and of the Council on energy efficiency 2012/27/EU, Official Journal EU no 27 of 14.11.2012.

[11] Trzaskalik, T. (2014). Wielokryterialne wspomaganie decyzji. Przegląd metod i zastosowań. Zeszyty Naukowe Politechniki Ślaskiej, Seria: Organizacja i zarzadzanie, 74.

[12] (2011). EAM. Energetyczny Audyt Miejski dla miasta Zielona Gora, Zadanie badawcze nr 1: Analysis of the possibilities and socio-economic impact of raise in energy efficiency in the construction industry. Umowa $\mathrm{Nr}$ SP/B/1/91454/10, NCBiR, Zielona Gora.

[13] Lączak, A. (2016). A comparative analysis of the EU coherence policy's influence on the innovation and competitiveness of central-eastern European states in the year 2004-2014. Acta Universitastis Lodzensis, Folia Oeconomica, 3(321), 35-53.

[14] Bazan-Krzywoszańska, A.; Łączak, A.; Mrówczyńska, M.; \& Skiba, M. (2016). Economic conditions for the development of energy efficient civil engineering using RES in the policy of cohesion of the European Union (2014-2020). Case study: The town of Zielona Gora. Energy and Buildings, 118, 170-180. https://doi.org/10.1016/j.enbuild.2016.02.048

[15] Aven T. (2015). Risk analysis. John Wiley \& Sons. https://doi.org/10.1002/9781119057819

[16] Jajuga, K. (2007). Teoretyczne podstawy zarządzania ryzykiem, [w:] K. Jajuga (red.), Zarządzanie Ryzykiem, Wyd. PWN, Warszawa.

[17] Hejmanowska, B. \& Hnat, E. (2009). Wielokryterialna analiza lokalizacji zabudowy na przykładzie gminy Podegrodzie. Archiwum Fotogrametrii, Kartografii $i$ Teledetekcji, 20, 109-121.

[18] Szwabowski, J. \& Deszcz, J. (2001). Metody wielokryterialnej analizy porównawczej. Podstawy teoretyczne $i$ przyktady zastosowań $w$ budownictwie. Wydawnictwo Politechniki Śląskie, Gliwice.

[19] GUS, Energy efficiency in 2001-2011.
[20] Choma, A. (2011). Zarządzanie ryzykiem, 4(8), 7-21. http://www.think.wsiz.rzeszow.pl (10.11.2016).

[21] Sisodia, G., Soares, I., \& Ferreira, P. (2016). Modeling business risk: The effect of regulatory revision on renewable energy investment - The Iberian case. Renewable Energy, 95, 303-313. https://doi.org/10.1016/j.renene.2016.03.076

[22] Chaves A. \& Bahill A. T. (2014). Comparison of Risk Analysis Approaches and a Case Study of the Risk of Incorporating Solar Photovoltaic Systems into a Commercial Electric Power Grid. Systems Engineering, 17(1), 89-111. https://doi.org/10.1002/sys.21254

[23] Mack, I. M. (2014). Energy Trading and Risk Management: A Practical Approach to Hedging, Trading and Portfolio Diversification. John Wiley \& Sons. https://doi.org/10.1002/9781118638286

[24] Skrzypczak, I., Buda-Ożóg, L., \& Pytlowany, T. (2016). Fuzzy method of conformity control for compressive strength of concrete on the basis of computational numerical analysis. Meccanica, 51(2), 383-389. https://doi.org/10.1007/s11012-015-0291-0

[25] Chalabi, Z., Das, P., Milner, J., Davies, M., Hamilton, I., Jones, B., Shrubsole, C., \& Wilkinson, P. (2015). Risk analysis of housing energy efficiency interventions under model uncertainty. Energy and Buildings, 109, 174-182. https://doi.org/10.1016/j.enbuild.2015.10.006

\section{Contact information:}

\section{Maria MRÓWCZYŃSKA, Professor}

University of Zielona Gora,

Faculty of Civil Engineering, Architecture and Environmental Engineering, 65-417 Zielona Gora, ul. Licealna 9, Poland

M.Mrowczynska@ib.uz.zgora.pl

\section{Andrzej $Ł A C Z A K, P h D$}

State School of Higher Professional Education in Sulechów,

Institute of Law and Tourism,

66-100 Sulechów, Army 51, Poland

a.laczak@pwsz.sulechow.pl

\section{Anna BAZAN-KRZYWOSZAŃSKA, PhD}

University of Zielona Gora,

Faculty of Civil Engineering, Architecture and Environmental Engineering, 65-417 Zielona Gora, ul. Licealna 9, Poland

A.Bazan@aiu.uz.zgora.pl

Marta SKIBA, PhD

University of Zielona Gora

Faculty of Civil Engineering, Architecture and Environmental Engineering, 65-417 Zielona Góra, ul. Licealna 9, Poland

M.Skiba@aiu.uz.zgora.pl 